\title{
Degradation of $A \alpha$ and $B \beta$ chains from bovine fibrinogen by serine proteases of the Amazonian scorpion Brotheas amazonicus
}

\author{
Andre Higa ${ }^{*}$, Maria das Dores Noronha ${ }^{2}$, Jorge Luis López-Lozano² \\ From 5th Congress of the Brazilian Biotechnology Society (SBBIOTEC) \\ Florianópolis, Brazil. 10-14 November 2013
}

\section{Background}

Proteolytic enzymes within venoms from different scorpion species belong to serine and metalloproteases class, and some isoforms of these enzymes show proteolytic activity over $A \alpha$ and $B \beta$ subunits of fibrinogen [1-3]. Brotheas amazonicus is a non-lethal amazonian scorpion, belonging to a different group from Tityus genus, and there are scarce studies about its venom in literature [4]. Enzymes acting over fibrinogen can lead to the creation of more efficient antithrombotic drugs, and the low lethality of $B$. amazonicus venom is a potencial factor for developing a better drug.

\section{Material and methods}

Venon was early incubated with metallo or serine proteases inhibitors (PMSF and EDTA), and proteolytic activity was evaluated by zymogram in SDS-PAGE using as substrate bovine fibrinogen. After electrophoresis, gel was rinsed with $2.5 \%$ Triton X-100. Gel was incubated in humid chamber for 24 hours at $37^{\circ} \mathrm{C}$, in $0.1 \mathrm{M}$ Glycine pH 8.3 solution. Dye was performed using $0.02 \%$ Comassie Blue R-250 solution. Proteolytic activity of B. amazonicus venom over bovine fibrinogen was tested, by mixing $200 \mu \mathrm{L}$ of fibrinogen solution $(2 \mu \mathrm{g} / \mu \mathrm{L})$ in $0.01 \mathrm{M}$ PBS pH 7.4 with $50 \mu \mathrm{g}$ of B. amazonicus venom, for 12 hours at $37^{\circ} \mathrm{C}$. After this process, no clots were observed, so $5 \mu \mathrm{g}$ of Bothrops atrox venom [5] was incorporated to the system, but also no clotting was observed, suggesting $B$. amazonicus venom had activity over fibrinogen, but with no clotting formation. Changes induced by B. amazonicus venom on bovine fibrinogen were evaluated by $12 \%$ SDS-PAGE electrophoresis stained with silver

${ }^{1}$ Universidade do Estado do Amazonas, Manaus, Amazonas, Brazil Full list of author information is available at the end of the article nitrate. Inhibition efficacy of fibrinogenolytic activity of B. amazonicus venom by anti-scorpionic serum was tested, by adding different concentrations of anti-venom in $200 \mu \mathrm{L}$ of bovine fibrinogen $(2 \mu \mathrm{g} / \mu \mathrm{L})$ plus $5 \mu \mathrm{g}$ of $B$. amazonicus venom. This system was incubated for 24 hours at $37^{\circ} \mathrm{C}$, and after this process clotting induction by $5 \mu \mathrm{g}$ of $B$. atrox venom was performed.

\section{Results and conclusion}

Proteolytic activity of $B$. amazonicus venom over bovine fibrinogen was only inhibited by PMSF - specific inhibitor for serine proteases. B. amazonicus venom degraded bovine fibrinogen without fibrin clots formation, confirmed by clots absence when $B$. atrox venom was incorporated to the system. In SDS-PAGE electrophoresis of degraded fibrinogen, it was possible to detect that $B$. amazonicus venom degraded $A \alpha$ and $B \beta$ subunits of fibrinogen, and anti-scorpionic serum specific for Tityus species shows great neutralizing efficacy when 1:1 proportion, suggesting that $B$. amazonicus toxins show similar antigenic properties of serine proteases from Tityus genus venom. Results suggest a serine protease with bovine fibrinogen affinity, able to degrade different regions from this molecule unlike thronbin and with a high similarity of proteases from Tityus sp. Such characteristics, plus the fact that this venom has a low toxicity, make these proteases inside $B$. amazonicus venom as candidates for antithrombotic drugs or even vaccines against scorpionic accidents.

\section{Acknowledgements}

Amazonas State Government, Brazilian Ministry of Science and Technology and National Council of Development in Research and Technology (CNPq)

\section{Authors' details}

'Universidade do Estado do Amazonas, Manaus, Amazonas, Brazil. ${ }^{2}$ Fundação de Medicina Tropical Doutor Heitor Vieira Dourado, Manaus, Brazil. 


\section{References}

1. Almeida FM, Pimenta AM, de Figueiredo SG, Santoro MM, Martin-

Eauclaire MF, Diniz CR, de Lima ME: Enzymes with gelatinolytic activity can be found in Tityusbahiensis and Tityusserrulatus venoms. Toxicon 2002, 40(7):199-203.

2. Araújo TF, Higa AM, Noronha MDN, Martins MJP, Muniz EG, Medeiros BM, Aguiar NO, López-Lozano JL: Proteolytic activity of amazonian scorpion Tityus metuendus venom (Scorpiones: Buthidae). J Venom Anim Toxins incl Trop Dis 2007, 13(1):254.

3. Possani LD, Martin BN, Fletcher MD, Fletcher PL Jr: Discharge effect on pancreatic exocrine secretion produced toxins purified from Tityus serrulatus scorpion venom. J Biomol Chem 1991, 266:3178-3185.

4. Lourenço WR, Adis J: Amazonian Arachnida and Myriapoda. 2007, 4(9):399-438.

5. López-Lozano JL, Valle de Sousa M, Ricart CAO, Chávez-Olortegui C, FloresSánchez E, Muniz EG, Bührnheim PF, Morhy L: Ontogenetic variation of metalloproteinases and plasma coagulant activity in venoms of wild Bothrops atrox specimens from Amazonian rain forest". Toxicon 2002, 40:997-1006.

doi:10.1186/1753-6561-8-S4-P12

Cite this article as: Higa et al:: Degradation of $A \alpha$ and $B \beta$ chains from bovine fibrinogen by serine proteases of the Amazonian scorpion Brotheas amazonicus. BMC Proceedings 2014 8(Suppl 4):P12.

\section{Submit your next manuscript to BioMed Central and take full advantage of:}

- Convenient online submission

- Thorough peer review

- No space constraints or color figure charges

- Immediate publication on acceptance

- Inclusion in PubMed, CAS, Scopus and Google Scholar

- Research which is freely available for redistribution

Submit your manuscript at www.biomedcentral.com/submit 